ASTHMA

\title{
Hormone replacement therapy, body mass index and asthma in perimenopausal women: a cross sectional survey
}

\author{
F Gómez Real, C Svanes, E H Björnsson, K Franklin, D Gislason, T Gislason, A Gulsvik, \\ C Janson, R Jögi, T Kiserud, D Norbäck, L Nyström, K Torén, T Wentzel-Larsen, \\ E Omenaas
}

See end of article for authors' affiliations

Correspondence to: Dr F Gómez Real, Department of Gynecology and Obstetrics, Haukeland University Hospital, 5021 Bergen, Norway;

francisco.real@med.vib.no

Received 18 January 2005 Accepted 13 October 2005 Published Online First 21 October 2005

Background: Hormone replacement therapy (HRT) and obesity both appear to increase the risk of asthma. A study was undertaken to investigate the association of HRT with asthma and hay fever in a population of perimenopausal women, focusing on a possible interaction with body mass index (BMI).

Methods: A postal questionnaire was sent to population based samples in Denmark, Estonia, Iceland, Norway, and Sweden in 1999-2001, and 8588 women aged 25-54 years responded (77\%). Pregnant women, women using oral contraceptives, and women $<46$ years were excluded. Analyses included 2206 women aged 46-54 years of which 884 were menopausal and 540 used HRT. Stratified analyses by $B M I$ in tertiles were performed.

Results: HRT was associated with an increased risk for asthma (OR $1.57(95 \% \mathrm{Cl} 1.07$ to 2.30$)$ ), wheeze (OR $1.60(95 \% \mathrm{Cl} 1.22$ to 2.10$)$ ), and hay fever (OR 1.48 (95\% Cl 1.15 to 1.90$)$ ). The associations with asthma and wheeze were significantly stronger among women with BMl in the lower tertile (asthma OR 2.41 (95\% Cl 1.21 to 4.77); wheeze OR 2.04 (95\% Cl 1.23 to 3.36)) than in heavier women (asthma: $\mathrm{p}_{\text {interaction }}=0.030$; wheeze: $p_{\text {interaction }}=0.042$ ). Increasing $B M I$ was associated with more asthma (OR $1.08(95 \% \mathrm{Cl} 1.05$ to 1.12$\left.) \mathrm{per} \mathrm{kg} / \mathrm{m}^{2}\right)$. This effect was only found in women not taking HRT (OR 1.10 $(95 \% \mathrm{Cl} 1.05$ to 1.14$)$ per kg/m²); no such association was detected in HRT users (OR 1.00 (95\% Cl 0.92 to 1.08$) \mathrm{per} \mathrm{kg} / \mathrm{m}^{2}$ ) ( interaction $=0.046$ ). Menopause was not significantly associated with asthma, wheeze, or hay fever.

Conclusions: In perimenopausal women there is an interaction between HRT and BMI in the effects on asthma. Lean women who were HRT users had as high a risk for asthma as overweight women not taking HRT. It is suggested that HRT and overweight increase the risk of asthma through partly common pathways.

$\mathrm{H}$ ormonal replacement therapy (HRT) as a remedy for menopausal symptoms has long seemed to be biologically plausible, although there has been no firm assessment of its side effects. As a result of the Women's Health Initiative $^{1}$ and other trials, ${ }^{2}$ in the last few years there has been an increasing awareness of the risks of HRT, mainly on cardiovascular diseases, stroke, venous thromboembolism, and breast cancer. Less attention has been paid to the effects of HRT on the airways, even though there is mounting-but somewhat contradictory-evidence of an association between HRT and obstructive airways disease.

Data from the Nurses Health Study ${ }^{3}$ and the Copenhagen City Heart Study ${ }^{5}$ show that women taking HRT are more likely to have asthma. In an elderly US Medicare population, ${ }^{6}$ HRT users had higher lung function. Small intervention and case-control studies in selected healthy women generally show an improvement in asthma or lung function related to HRT intake. ${ }^{78}$ The apparently contradictory findings may be caused by unrecognised sources of error in some studies. ${ }^{9}$ Another possibility is that the effects of HRT differ between subgroups of women of different ages, ${ }^{9}$ metabolic conditions, ${ }^{10-14}$ or menopausal status. ${ }^{15}$

The association of asthma with BMI is well known although not fully understood. ${ }^{16-18}$ Sex hormones and body fat mass are closely interrelated; the levels of oestrogens are related to body fat mass ${ }^{912}$ and the subject's metabolic status. ${ }^{19}$ Exogenous estrogens and BMI are known to interact

in their effects on breast cancer; the increase in breast cancer risk related to HRT is stronger in lean women. ${ }^{20}$

Initiation of menopause may possibly also play a role in the development of asthma; asthma may sometimes start or worsen around the age of menopause, ${ }^{15}$ but has also been reported to be less common among postmenopausal women. ${ }^{3}$

We wanted to investigate the possible associations of HRT and menopause with symptoms of asthma and allergy among perimenopausal women in general population samples from Northern European countries with different prescription practices, ${ }^{21}$ particularly the possible heterogeneity in the effects of HRT according to BMI.

\section{METHODS}

\section{Study design and subjects}

The study was a cross sectional analysis of the Respiratory Health in Northern Europe (RHINE, www.rhine.nu). ${ }^{16} 22$ RHINE is a follow up study of subjects from seven Northern European centres who participated in the European Community Respiratory Health Survey (ECRHS) I stage 1 (www.ecrhs.org), a study that took place in 1990-4. ${ }^{23}$ In stage 1 of the ECRHS men and women aged 20-44 years were randomly selected from population registers within specific boundaries of each participating centre. A postal

Abbreviations: BMI, body mass index; ECRHS, European Community Respiratory Health Survey; HRT, hormone replacement therapy; IR, insulin resistance; RHINE, Respiratory Health in Northern Europe 
Table 1 Characteristics of women aged $46-54$ years participating in the RHINE study

\begin{tabular}{|c|c|c|c|c|c|c|c|c|c|}
\hline Centre & $\begin{array}{l}\text { Study } \\
\text { population } \\
\text { (N) }\end{array}$ & $\begin{array}{l}\text { Median } \\
\text { age } \\
\text { (years) }\end{array}$ & $\begin{array}{l}\text { Median } \\
\text { BMI } \\
\left(\mathrm{kg} / \mathrm{m}^{2}\right)\end{array}$ & $\begin{array}{l}\text { Current } \\
\text { smokers } \\
(\%)\end{array}$ & $\begin{array}{l}\text { Menopausal }{ }^{*} \\
\mathbf{n}(\%)\end{array}$ & $\begin{array}{l}\text { HRT } \\
\text { n (\%) }\end{array}$ & $\begin{array}{l}\text { Asthmat } \\
\text { (\%) }\end{array}$ & $\begin{array}{l}\text { Wheeze‡ } \\
\text { (\%) }\end{array}$ & $\begin{array}{l}\text { Hay fever§ } \\
\text { (\%) }\end{array}$ \\
\hline Aarhus & 328 & 49 & 23.5 & 34 & 92 (32) & $37(11)$ & 9.2 & 17 & 23 \\
\hline Reykjavik & 323 & 49 & 24.8 & 27 & $145(51)$ & 157 (49) & 8.1 & 12 & 23 \\
\hline Bergen & 345 & 49 & 23.4 & 39 & 191 (57) & $103(30)$ & 7.3 & 22 & 23 \\
\hline Gothenburg & 326 & 49 & 24.6 & 34 & $113(43)$ & $78(24)$ & 9 & 25 & 27 \\
\hline Umeå & 398 & 49 & 24.5 & 24 & $154(41)$ & $79(20)$ & 8.1 & 21 & 22 \\
\hline Uppsala & 375 & 49 & 24 & 19 & $123(35)$ & 81 (22) & 6.8 & 19 & 26 \\
\hline Tartu & 111 & 47 & 24.6 & 24 & $26(24)$ & $5(4.5)$ & 3.6 & 23 & 25 \\
\hline Total & 2206 & 49 & 24.2 & 29 & $844(42)$ & $540(24)$ & 7.8 & 20 & 24 \\
\hline
\end{tabular}

"Menopause as defined as answering "yes" to the question: "Have you reached the menopause (6 or more months since your last menstruation)?". tCurrent asthma medication and/or asthma attacks in the last 12 months. $\ddagger$ Wheeze in the last 12 months.

$\S$ Current hay fever or nasal allergies.

questionnaire was sent to $3000-4300$ subjects in each centre. The population included in the RHINE study consisted of responders from Reykjavik in Iceland, Bergen in Norway, Umeå, Uppsala and Gothenburg in Sweden, Aarhus in Denmark, and Tartu in Estonia $(n=21$ 802, response rate 83.7\%). The eligible subjects (excluding 264 deaths) were sent a postal questionnaire in 1999-2001. Subjects not responding to the first mailing were sent two reminders. In total, 16191 subjects answered the questionnaire including 8588 women (response rate $77 \%$ ) born between 1945 and 1973.

Analyses were restricted to women aged $46-54$ years since the mean age of onset of the perimenopausal transition is 4546 years. ${ }^{24}$ Pregnant women $(n=6)$ and women using oral contraceptives $(n=72)$ were excluded, leaving 2206 women for analyses.

There were 121 women younger than 46 years who reported menopause, and 102 of these were taking HRT. The age group 26-45 was not included in further analyses because pathological conditions underlying early menopause might introduce unknown confounders, and because the 19 younger menopausal women not taking HRT would constitute a small and possibly biased reference group.

\section{Questionnaire}

The first part of the questionnaire contained 12 questions identical to those asked in the ECRHS I stage 1. These items covered respiratory symptoms, asthma medication, and hay fever. Asthma was defined as currently using asthma medication and/or having had asthma attacks during the last 12 months, wheeze as having had wheeze during the last
12 months, night symptoms as waking with tightness in chest or waking with shortness of breath, and hay fever as currently having hay fever or nasal allergies. Three or more asthma symptoms were defined based on the following eight symptoms: wheeze, wheeze with shortness of breath, wheeze without cold, waking with tightness in chest, waking with shortness of breath, waking with cough, asthma attacks, and current asthma medication. ${ }^{25}$

The second part of the questionnaire included 52 items covering various aspects including factors related to hormonal status in women. Menopause was defined as answering "yes" to the question "Have you reached the menopause (6 or more months since your last menstruation)?". HRT was defined as answering "yes" to the question "Are you using hormones/hormone replacement therapy?". In some centres HRT was only registered in women answering "yes" to having reached the menopause. The women were also asked about pregnancy, use of oral contraceptives, age of menopause, and date of the last menstrual bleeding.

BMI was based on self-reported weight and height and calculated as $\mathrm{kg} / \mathrm{m}^{2}$. Smoking history was assessed by two questions: "Are you a smoker?" and "Are you an exsmoker?" Based on these, three groups were defined (never smokers, ex-smokers, and current smokers). Type of dwelling (detached, semi-detached, apartment, other) was used as a proxy for social class, "detached" corresponding to upper social class, etc. A socioeconomic index based on current occupation was available in four centres (Bergen, Gothenburg, Uppsala, and Tartu). In these centres the type of dwelling was strongly correlated with socioeconomic index

Table 2 Asthma and hay fever according to menopause in 1527 women aged 4654 years (women using HRT were excluded)

\begin{tabular}{|c|c|c|c|c|}
\hline & $\begin{array}{l}\text { Premenopausal } \\
(n=1103) \\
(\%)\end{array}$ & $\begin{array}{l}\text { Postmenopausal } \\
(n=424) \\
(\%)\end{array}$ & OR $(95 \% \mathrm{CI})^{*}$ & p value \\
\hline Asthma† & 6.9 & 7.2 & $0.94(0.57$ to 1.55$)$ & 0.8 \\
\hline Wheeze & 17 & 21 & $1.18(0.85$ to 1.14$)$ & 0.3 \\
\hline $\begin{array}{l}\text { Three or more asthma } \\
\text { symptoms } \S\end{array}$ & 13 & 16 & $1.11(0.76$ to 1.63$)$ & 0.6 \\
\hline Night symptoms** & 13 & 17 & $1.36(0.96$ to 1.93$)$ & 0.088 \\
\hline Hay fevert† & 23 & 21 & $0.97(0.71$ to 1.32$)$ & 0.8 \\
\hline Allergic asthmał‡ & 4.4 & 2.6 & $0.54(0.26$ to 1.13$)$ & 0.1 \\
\hline
\end{tabular}

*From logistic regression models with adjustment for smoking, BMI, age, centre, and social class. †Asthma medication and/or asthma attacks in the last 12 months. $\mp$ Wheeze in the last 12 months.

§Symptoms included: wheeze, wheeze with shortness of breath, wheeze without cold, waking with tightness in chest, waking with shortness of breath, waking with cough, asthma attacks, current asthma medication. **Waking with tightness in chest or waking with shortness of breath. ††Hay fever or nasal allergies. ¥Asthma and hay fever. 
Table 3 Asthma and hay fever according to HRT use in 2206 women aged 46-54 years

\begin{tabular}{|c|c|c|c|c|}
\hline & $\begin{array}{l}\text { No HRT } \\
(\mathrm{n}=1666) \\
(\%)\end{array}$ & $\begin{array}{l}\text { HRT } \\
(n=540) \\
(\%)\end{array}$ & OR $(95 \% \mathrm{CI})^{*}$ & p value \\
\hline Asthmat & 7.2 & 10.0 & 1.50 (1.03 to 2.20$)$ & 0.035 \\
\hline Wheezef & 18.7 & 23.1 & 1.54 (1.17 to 2.02$)$ & 0.002 \\
\hline Three or more symptoms§ & 13.3 & 18.5 & $1.62(1.20$ to 2.20$)$ & 0.002 \\
\hline Night symptoms ${ }^{* *}$ & 14.2 & 11.8 & 0.85 (0.61 to 1.18$)$ & 0.3 \\
\hline Hay fever†† & 23.0 & 27.4 & 1.47 (1.14 to 1.88$)$ & 0.003 \\
\hline Allergic asthmał‡ & 3.9 & 5.8 & 1.77 (1.09 to 2.89$)$ & 0.022 \\
\hline
\end{tabular}

*From logistic regression models with adjustment for smoking habits, BMI, age, centre, and social class. †Asthma medication and/or asthma attacks in the last 12 months. Wheeze in the last 12 months.

$\S$ Symptoms included: wheeze, wheeze with shortness of breath, wheeze without cold, waking with tightness in chest, waking with shortness of breath, waking with cough, asthma attacks, current asthma medication. **Waking with tightness in chest or waking with shortness of breath.

†† Hay fever or nasal allergies.

¥Аsthma and hay fever.

$(\mathrm{p}<0.001)$, and analyses with adjustment for this variable gave similar results as when adjusting for type of dwelling.

\section{Statistical analysis}

Logistic regression models were used to assess the effects of menopause and of HRT on asthma and hay fever. The number at risk fluctuated slightly from outcome to outcome because of a varying number of missing data for each variable. Adjustments were made for age ( 5 year categories), BMI $\left(\mathrm{kg} / \mathrm{m}^{2}\right)$, smoking habits (never, ex, and current smoking), study centre, and social class (type of dwelling).

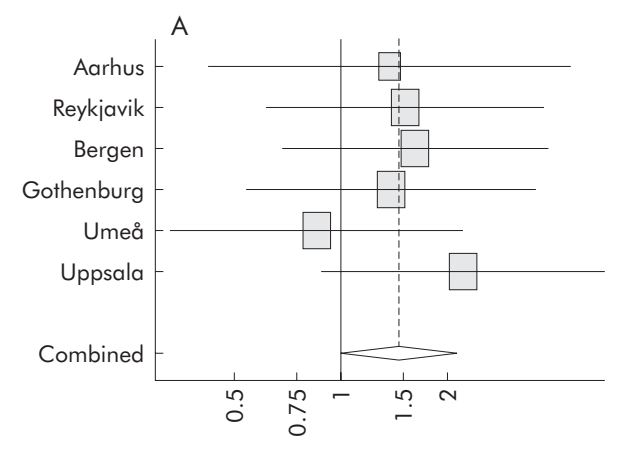

OR for effect of HRT on asthma

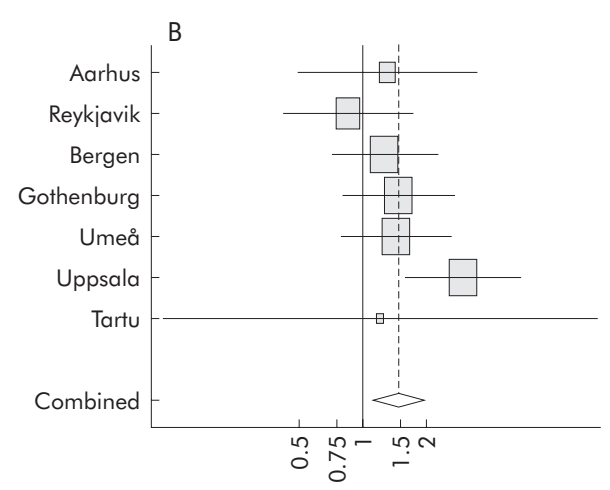

OR for effect of HRT on wheeze

Figure 1 Odds ratios for the associations between (A) HRT and asthma by centre (Tartu not included because of small numbers) and (B) HRT and wheeze by centre. Adjustment within centre for smoking habits, BMI, age, and social class. For each centre, horizontal lines indicate $95 \% \mathrm{Cl}$. For combined OR, diamond indicates $95 \% \mathrm{Cl}$ from model with centre as random effect. The size of each square is proportional to the sample size.
Analyses of HRT were stratified according to BMI categorised in tertiles. Based on the results from the stratified analyses, the two upper tertiles were grouped together post hoc and the differences in the effects of HRT on asthma between lean and heavier women were analysed by including interaction terms of BMI and HRT in the logistic regression models. Similarly, logistic regression models were used to assess the effects of BMI (as a continuous variable) on asthma and hay fever; analyses were stratified by HRT use and an interaction term between BMI and HRT was included to assess the statistical significance of differences in BMI effects between subjects using or not using HRT. Potential heterogeneity between centres was studied by meta-analyses according to derSimonian and Laird. The analyses were carried out using the statistical software program Stata 7.0 (Stata Corporation, College Station, Texas, USA).

\section{RESULTS}

Of 2206 women aged 46-54 years, 540 (24\%) were using HRT at the time of the study. There was some variation between centres, with HRT being more widely used in Reykjavik and Bergen and less used in Tartu and Aarhus compared with the Swedish centres (table 1). In total, 844 women reported that they were menopausal (table 1). Women taking HRT were leaner, were more often smokers, and more often lived in a semi-detached house than women not taking HRT.

Asthma, wheeze, or hay fever did not differ significantly between premenopausal and postmenopausal women, while there was a borderline significant association between night symptoms and menopause (table 2).

Asthma, asthma symptoms and hay fever, but not night symptoms, were significantly more common among women using HRT (table 3). There was no significant heterogeneity between centres in the association of HRT with asthma or wheeze ( $p_{\text {heterogeneity }}=0.84$ and 0.35 for asthma and wheeze, respectively; fig 1 ).

When stratifying by BMI in tertiles, HRT was significantly associated with a higher risk for asthma, wheeze and hay fever only among lean women (table 4). The associations between HRT and asthma and wheeze in women in the lower BMI tertile were significantly stronger than the corresponding associations in women in the medium and upper tertiles $\left(p_{\text {interaction }}=0.020\right.$ and 0.026 , respectively $)$.

Increasing BMI was associated with more asthma and asthma symptoms, but not with hay fever (table 5).

Stratifying by use of HRT, an association between asthma and BMI was observed in women not taking HRT (OR 1.10; $95 \%$ CI 1.05 to 1.14 per $\mathrm{kg} / \mathrm{m}^{2}$; fig $2 \mathrm{~A}$ ) while no such association could be detected in women taking HRT (OR 1.00; 
Table 4 Asthma and hay fever in women according to HRT use stratified by BMI in tertiles

\begin{tabular}{|c|c|c|c|c|}
\hline & $\begin{array}{l}\text { No HRT } \\
(\%)\end{array}$ & $\begin{array}{l}\text { HRT } \\
(\%)\end{array}$ & OR $(95 \% \mathrm{Cl})^{*}$ & $\mathrm{p}$ value \\
\hline \multicolumn{5}{|c|}{ Lower tertile $B M I<22.76(n=716)$} \\
\hline Asthmat & 5.3 & 12.0 & $2.28(1.18 \text { to } 4.40)^{* *}$ & 0.014 \\
\hline Wheezeł & 14.9 & 25.8 & $1.85(1.16$ to 2.96$) \mathrm{tt}$ & 0.010 \\
\hline Hay fever§ & 20.7 & 29.7 & $2.06(1.33$ to 3.19$) \neq \ddagger$ & 0.001 \\
\hline \multicolumn{5}{|c|}{ Medium tertile BMI 22.76-25.71 ( $n=736)$} \\
\hline Asthma† & 5.6 & 6.3 & $1.28(0.61 \text { to } 2.71)^{\star *}$ & 0.513 \\
\hline Wheezeł & 15.0 & 19.7 & $1.56(0.95$ to 2.54$)+\dagger$ & 0.076 \\
\hline Hay fever§ & 23.1 & 25.3 & $1.20(0.79$ to 1.84$) \pm \ddagger$ & 0.395 \\
\hline \multicolumn{5}{|c|}{ Upper tertile BMI > 25.71 $(n=709)$} \\
\hline Asthmat & 10.6 & 12.4 & $1.31(0.71 \text { to } 2.42)^{* *}$ & 0.382 \\
\hline Wheezeł & 24.1 & 26.7 & $1.28(0.80$ to 2.06$)+\dagger$ & 0.302 \\
\hline Hay fever§ & 25.0 & 26.9 & $1.39(0.89$ to 2.17$)$ tł & 0.153 \\
\hline
\end{tabular}

*From logistic regression models with adjustment for smoking habits, BMI (within tertile), age, centre, and type of dwelling (as a proxy for social class).

†Asthma medication and/or asthma attacks in the last 12 months.

\#Wheeze in the last 12 months.

$\S$ Hay fever or nasal allergies.

**Interaction in effect of HRT on asthma between lean and normal/overweight women $p_{\text {interaction }}=0.020$.

t†lnteraction in effect of HRT on wheeze between lean and normal/overweight women pinteraction $=0.026$.

t+lnteraction in effect of HRT on hay fever between lean and normal/overweight women $p_{\text {interaction }}=0.076$.

95\% CI 0.92 to 1.08 per $\mathrm{kg} / \mathrm{m}^{2}$; fig 2B). The difference in the associations between asthma and BMI according to use of HRT was significant $\left(p_{\text {interaction }}=0.046\right)$.

The associations between HRT and asthma, wheeze and hay fever were only significant in never smokers (table 6), although the differences between smoking groups were not significant $\left(p_{\text {interaction }}=0.19,0.6\right.$, and 0.4 for asthma, wheeze and hay fever, respectively).

\section{DISCUSSION}

The prevalence of diagnosed asthma, asthma symptoms, and allergy was higher among HRT users in a multicentre, population based, cross sectional survey of Northern European perimenopausal women. This was consistent between centres with different prescription practices. The risk for asthma related to HRT use was significantly greater in lean women than in heavier women, and this interaction in the effects of HRT and BMI on asthma was significant. The well documented association of asthma with BMI was observed only in women not taking exogenous sex hormones, while no significant association between asthma and BMI was found among HRT users. Exogenous oestrogens therefore appear to interfere with the mechanism causing more asthma among overweight women, resulting in a similar high prevalence of asthma in lean HRT users as that observed in obese women not taking HRT.

The observed higher prevalence of asthma among HRT users is in agreement with findings from the two large cohort studies, the Copenhagen City Heart Study and the Nurses' Health Study. ${ }^{3-5}$ The interaction between BMI and HRT in the effects on asthma is supported by the Nurses' Health Study in which the relative risk for HRT on asthma was 3.09 in lean women and 1.58 in heavier women. ${ }^{4}$ An association between HRT and hay fever has not been reported previously. Our study supports the findings of Lange et $a l^{5}$ who noted a stronger association of HRT with asthma among never smokers, possibly due to anti-oestrogen effects of smoking. ${ }^{26}$ Our findings are not necessarily contradictory to those of Carlson et $a l^{6}$ as we did not have data on lung function and our study population comprised much younger women.

The main limitation of the present study is its cross sectional design. Due to the lack of information about when the women started using HRT, we do not know with certainty

Table 5 Asthma and hay fever according to BMl in tertiles, and adjusted associations of $\mathrm{BMI}$ with asthma and hay fever

\begin{tabular}{|c|c|c|c|c|}
\hline & $\begin{array}{l}\text { Lower tertile } \\
\text { BMI <22.76 } \\
(n=716) \\
(\%)\end{array}$ & $\begin{array}{l}\text { Medium tertile } \\
22.76<\text { BMl }<25.71 \\
(\mathrm{n}=736) \\
(\%)\end{array}$ & $\begin{array}{l}\text { Upper tertile } \\
\text { BMI > 25.71 } \\
(\mathrm{n}=709) \\
(\%)\end{array}$ & $\begin{array}{l}\text { OR }(95 \% \mathrm{Cl})^{*} \\
\left(\text { per } \mathrm{kg} / \mathrm{m}^{2}\right)\end{array}$ \\
\hline Asthma† & 6.9 & 5.8 & 11 & 1.08 (1.05 to 1.12$)$ \\
\hline Wheezef & 17.4 & 16.2 & 26.1 & 1.09 (1.06 to 1.12$)$ \\
\hline $\begin{array}{l}\text { Three or more } \\
\text { symptoms } \S\end{array}$ & 11.5 & 11.9 & 20.7 & 1.10 (1.07 to 1.13$)$ \\
\hline Night symptoms** & 10.9 & 12.8 & 17.1 & 1.06 (1.03 to 1.09$)$ \\
\hline Hay fevert† & 22.8 & 23.7 & 25.5 & $1.02(0.99$ to 1.04$)$ \\
\hline Allergic asthmał‡ & 4.1 & 3.7 & 5.1 & $1.04(1.00$ to 1.10$)$ \\
\hline
\end{tabular}

*From logistic regression models with adjustment for smoking habits, BMI, age, centre and social class †Asthma medication and/or asthma attacks last 12 months.

$¥$ Wheeze in the last 12 months

§Symptoms included: wheeze, wheeze with shortness of breath, wheeze without cold, waking with tightness in chest, waking with shortness of breath, waking with cough, asthma attacks, current asthma medication

**Waking with tightness in chest or waking with shortness of breath

††Hay fever or nasal allergies.

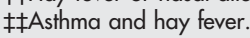



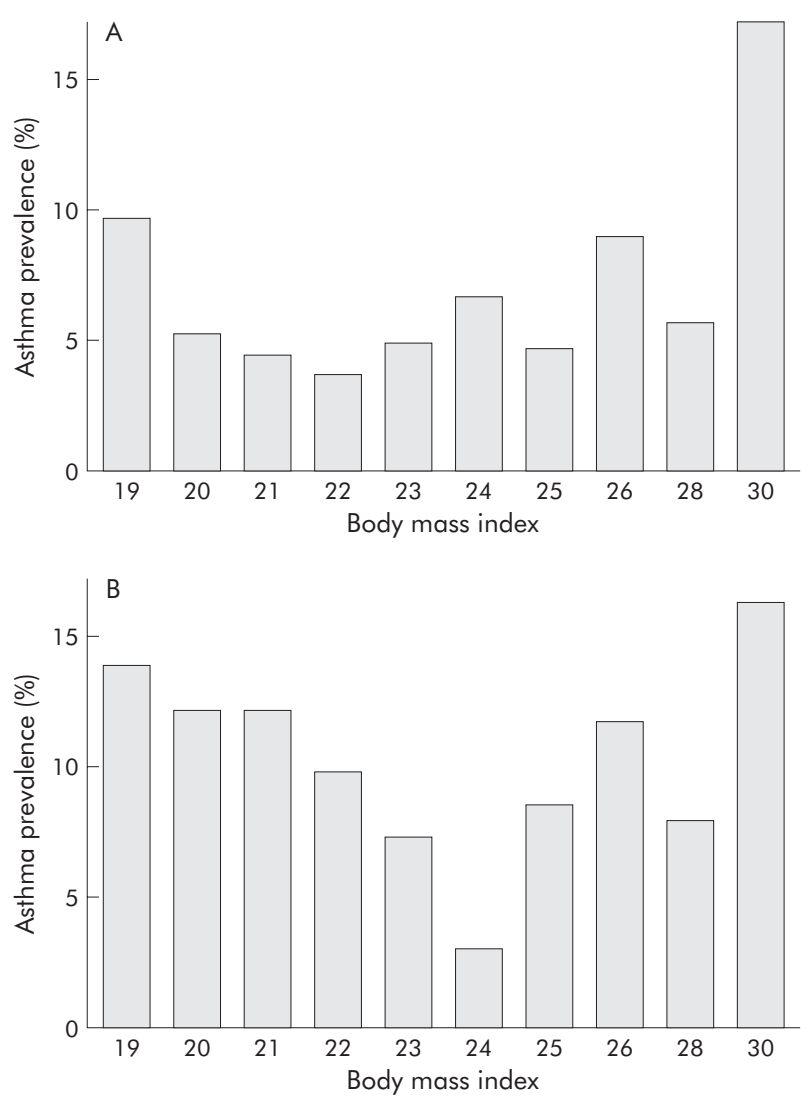

Figure 2 Asthma prevalence according to $B M I$ in (A) 1648 subjects not taking HRT and (B) 535 subjects taking HRT.

whether or not HRT preceded asthma. Self-reported use of HRT is considered to be reliable. ${ }^{27}$ We did not have information about the type of HRT, but Barr et al ${ }^{4}$ did not observe differences with regard to type of HRT. Differential misclassification of asthma related to HRT use is a possibility; women taking HRT might have their asthma diagnosed more often because of a higher health awareness or more frequent contact with a doctor. The association between asthma and obesity might also be influenced by doctor bias. However, it seems unlikely that these sources of error explain our findings because the associations were consistent between centres with different prescription practices, the findings were similar for doctor diagnosed asthma and asthma symptoms such as wheeze, adjustment for social class did not alter the effects, and the associations between asthma and HRT differed significantly between lean women and those of normal weight. This interaction between HRT and BMI is biologically plausible but difficult to attribute to systematic error.

Women in the age group 46-54 years as included in this study are usually in the perimenopausal transition. The mean age of onset for the perimenopausal transition is 46 years and the mean duration is 5 years. ${ }^{24}$ This is the age when the climacteric symptoms are most frequent and the use of HRT most relevant. There is a possibility for residual confounding by menopausal status, but self-reported menopausal status is considered reliable even though some caution must be exerted..$^{28}$ Differential misclassification of respiratory night symptoms as related to menopause could be suspected; night symptoms as opposed to other asthma symptoms appeared to be more common in menopausal women and less common in those taking HRT. There are some discrepancies in the current available literature about the role the onset of menopause plays in the development of pre-existing or new asthma and allergy. Some studies show a reduced asthma risk in naturally menopausal women ${ }^{3}$ while others suggest that asthma may start or worsen with the menopause. ${ }^{15}$ In our study menopause in itself was not significantly associated with asthma or hay fever.

Our study shows that the association between HRT and asthma appears to be modified by BMI. This is biologically plausible as there is a close interplay between sex hormones, fatty tissue, and metabolic status. A similar interaction has been described for breast cancer where the increase in relative risk among HRT users was greatest in lean women. ${ }^{20}{ }^{29}$ The association between asthma and BMI is well documented although not fully understood..$^{16-18} \mathrm{BMI}$ is closely related to insulin resistance (IR), ${ }^{30}{ }^{31}$ and we suggest that the association between asthma and BMI may be due to the proinflammatory effects of IR. ${ }^{31-33}$ There is no direct evidence linking asthma with IR, but several studies have shown an association between lung function and $\mathrm{IR}^{33-35}$ and a previous analysis of the present population showed an association between asthma and menstrual irregularity which is often a manifestation of IR. ${ }^{22}$

The effects of oestrogens on the airways appear to be complex. Both direct pro-inflammatory effects ${ }^{36}{ }^{37}$ and indirect beneficial metabolic effects are described. ${ }^{38}$ Oestrogens are closely related to BMI, which is the strongest marker of oestrogen levels in postmenopausal women. ${ }^{9}{ }^{12}$ IR is intimately involved in the regulation of local oestrogen

\begin{tabular}{|c|c|c|c|c|}
\hline & $\begin{array}{l}\text { No HRT } \\
\text { (\%) }\end{array}$ & $\begin{array}{l}\text { HRT } \\
\text { (\%) }\end{array}$ & OR $(95 \% \mathrm{Cl})^{*}$ & $p$ value \\
\hline \multicolumn{5}{|c|}{ Never smokers $(n=907)$} \\
\hline Asthma† & 5.3 & 9.2 & 2.42 (1.24 to 4.72 ) & 0.010 \\
\hline Wheeze $\ddagger$ & 13.1 & 17.2 & $1.94(1.18$ to 3.19$)$ & 0.008 \\
\hline Hay fever§ & 23.6 & 30.4 & $1.85(1.23$ to 2.78$)$ & 0.003 \\
\hline \multicolumn{5}{|c|}{ Ex-smokers $(n=684)$} \\
\hline Asthmat & 8.1 & 9.7 & $1.20(0.61$ to 2.33$)$ & 0.589 \\
\hline Wheeze $\neq$ & 14.9 & 19.5 & 1.66 (0.99 to 2.77$)$ & 0.050 \\
\hline Hay fever§ & 23.4 & 27.2 & $1.39(0.89$ to 2.18$)$ & 0.143 \\
\hline \multicolumn{5}{|c|}{ Smokers $(n=649)$} \\
\hline Asthma† & 9.1 & 11.5 & $1.41(0.74$ to 2.71$)$ & 0.293 \\
\hline Wheeze $\neq$ & 31.9 & 33.5 & $1.34(0.87$ to 2.06$)$ & 0.183 \\
\hline Hay fever§ & 22.1 & 24.1 & $1.18(0.73$ to 1.91$)$ & 0.488 \\
\hline
\end{tabular}

*From logistic regression models with adjustment for smoking habits, BMI (within tertile), age, centre, and type of dwelling (as a proxy for social class).

†Asthma medication and/or asthma attacks in the last 12 months.

$\ddagger$ Wheeze in the last 12 months.

§Hay fever or nasal allergies. 
production. $^{13} 19$ We therefore hypothesise that exogenous oestrogens and BMI act on the airways in part through common pathways, where inflammation associated with IR might have an important role. In lean women with low IR the direct pro-inflammatory effects of HRT could be predominant, while in heavier and more insulin resistant women such effects might be counterbalanced by an oestrogen related reduction in IR.

In conclusion, our study shows an association between HRT and asthma and hay fever, and confirms the association of obesity with asthma. This study also reveals an interaction between HRT and BMI in the effects on asthma, HRT increasing the risk of asthma in lean women to the same level as that observed in obese women. These findings are fairly convincing as the interaction with BMI is biologically plausible and difficult to explain as error, even if the study design is not ideal. This study therefore indicates that asthma and allergy may be side effects of HRT, at least in subgroups of women. Furthermore, obesity and exogenous oestrogens may be involved in the pathogenesis of asthma through partly common pathways. Future studies of the effects of HRT on the airways should be conducted in representative general population samples, taking into account the possibility that the effects of oestrogens might be dependent on BMI or metabolic status. Likewise, further studies of asthma and BMI should take into consideration the hormonal status.

\section{ACKNOWLEDGEMENTS}

The following scientists in the Rhine study group are acknowledged for helpful contributions: T Blöndal, US Björnsdottir, G Boman, B Forsberg, D Gislason, A Gulsvik, M Gunnbjörnsdottir, E Juel Jensen, M-C Ledin, L Lillienberg, B Lundbäck, BN Lærum, E Norrman, A-C Olin, E Rydén, U Spetz-Nyström, K Stenudd Cashelunge, M Söderberg, J Talvik, A Tunsäter, G Wieslander.

\section{Authors' affiliations}

F Gómez Real, T Kiserud, Department of Gynecology and Obstetrics, Haukeland University Hospital, 5021 Bergen, Norway

F Gómez Real, C Svanes, A Gulsvik, Institute of Medicine, University of Bergen, Norway

C Svanes, A Gulsvik, E Omenaas, Department of Thoracic Medicine, Haukeland University Hospital, 5021 Bergen, Norway

E H Björnsson, D Gislason, T Gislason, Department of Pulmonary Medicine, Landspitali University Hospital, 105 Reykjavik, Iceland

K Franklin, Department of Pulmonary Medicine and Allergology, Umeå University, 90185 Umeå, Sweden

C Janson, D Norbäck, Department of Medical Sciences, Uppsala University, 75185 Uppsala, Sweden

R Jögi, Foundation Tartu University Clinics, Lung Clinic, 51014 Tartu, Estonia

L Nyström, Department of Public Health, Clinical Medicine and Epidemiology, Umeå University, 90185 Umeå, Sweden

K Torén, Department of Occupational and Environmental Medicine, Sahlgrenska University Hospital, 41266 Gothenburg, Sweden

T Kiserud, Institute of Clinical Medicine, University of Bergen, Norway T Wentzel-Larsen, E Omenaas, Centre for Clinical Research, Haukeland University Hospital, Bergen, Norway

FGR was supported by a grant from the Norwegian Research Council. The study was supported financially by the Icelandic Research Council, the Swedish Heart and Lung Foundation, the Vardal Foundation for Health Care Science and Allergy Research, the Swedish Association against Asthma and Allergy, the Norwegian Research Council project 135773/330, the Norwegian Asthma and Allergy Association, the Danish Lung Association, and the Estonian Science Foundation grant no 4350.

\section{Competing interests: none.}

The study was approved by local ethics committees in all the study centres.

\section{REFERENCES}

1 Rossouw JE, Anderson GL, Prentice RL, et al. Risks and benefits of estrogen plus progestin in healthy postmenopausal women: principal results from the Women's Health Initiative randomized controlled trial. JAMA 2002;288:321-33.

2 Cushman M, Legault C, Barrett-Connor E, et al. Effect of postmenopausal hormones on inflammation-sensitive proteins: the Postmenopausal Estrogen/Progestin Interventions (PEPI) Study. Circulation 1999; 100:717-22.

3 Troisi RJ, Speizer FE, Willett WC, et al. Menopause, postmenopausal estrogen preparations, and the risk of adult-onset asthma. A prospective cohort study. Am J Respir Crit Care Med 1995;152:1183-8.

4 Barr RG, Wentowski CC, Grodstein F, et al. Prospective study of postmenopausal hormone use and newly diagnosed asthma and chronic obstructive pulmonary disease. Arch Intern Med 2004;164:379-86.

5 Lange P, Parner J, Prescott E, et al. Exogenous female sex steroid hormones and risk of asthma and asthma-like symptoms: a cross sectional study of the general population. Thorax 2001;56:613-6.

6 Carlson CL, Cushman M, Enright PL, et al. Hormone replacement therapy is associated with higher $\mathrm{FEV}_{1}$ in elderly women. Am J Respir Crit Care Med $2001 ; 163: 423-8$.

7 Kos-Kudla B, Ostrowska Z, Marek B, et al. Effects of hormone replacement therapy on endocrine and spirometric parameters in asthmatic postmenopausal women. Gynecol Endocrinol 2001;15:304-11.

8 Pata Ö. The effects of hormone replacement therapy type on pulmonary functions in postmenopausal women. Maturitas 2003;46:213-8.

9 Grodstein F, Clarkson TB, Manson JE. Understanding the divergent data on postmenopausal hormone therapy. N Engl J Med 2003;348:645-50.

10 Fernandez-Real JM, Sanchis D, Ricart W, et al. Plasma oestrone-fatty acid ester levels are correlated with body fat mass in humans. Clin Endocrinol (Oxf) 1999:50:253-60

11 Carr MC. The emergence of the metabolic syndrome with menopause. J Clin Endocrinol Metab 2003;88:2404-11.

12 Figueroa A, Going SB, Milliken LA, et al. Body composition modulates the effects of hormone replacement therapy on growth hormone and insulin-like growth factor-l levels in postmenopausal women. Gynecol Obstet Invest 2002; 54:201-6.

13 Kalish GM, Barrett-Connor E, Laughlin GA, et al. Association of endogenous sex hormones and insulin resistance among postmenopausal women: results from the Postmenopausal Estrogen/Progestin Intervention Trial. J Clin Endocrinol Metab 2003;88:1646-52.

14 Lindheim SR, Presser SC, Ditkoff EC, et al. A possible bimodal effect of estrogen on insulin sensitivity in postmenopausal women and the attenuating effect of added progestin. Fertil Steril 1993;60:664-7.

15 Balzano G, Fuschillo S, Melillo G, et al. Asthma and sex hormones. Allergy 2001;56:13-20.

16 Gunnbjornsdottir MI, Omenaas E, Gislason T, et al. Obesity and nocturnal gastro-oesophageal reflux are related to onset of asthma and respiratory symptoms. Eur Respir J 2004;24:116-21.

17 Shaheen SO, Sterne JA, Montgomery SM, et al. Birth weight, body mass index and asthma in young adults. Thorax 1999:54:396-402.

18 Camargo CA Jr, Weiss ST, Zhang S, et al. Prospective study of body mass index, weight change, and risk of adult-onset asthma in women. Arch Intern Med 1999; 159:2582-8

19 Simpson E, Rubin G, Clyne C, et al. The role of local estrogen biosynthesis in males and females. Trends Endocrinol Metab 2000;11:184-8.

20 Collaborative Group on Hormonal Factors in Breast Cancer. Breast cancer and hormone replacement therapy: collaborative reanalysis of data from 51 epidemiological studies of 52,705 women with breast cancer and 108,411 women without breast cancer. Lancet 1997;350:1047-59.

21 Topo P, Koster A, Holte A, et al. Trends in the use of climacteric and postclimacteric hormones in Nordic countries. Maturitas 1995:22:89-95.

22 Svanes C, Real FG, Gislason T, et al. Association of asthma and hay fever with irregular menstruation. Thorax 2005;60:445-50.

23 Burney PG, Luczynska C, Chinn S, et al. The European Community Respiratory Health Survey. Eur Respir J 1994;7:954-60.

24 Speroff L, Glass RH, Kase NG. Menopause and the perimenopausal transition. In: Mitchell C, ed. Clinical gynecologic endocrinology and infertility. 6th ed. Baltimore: Lippincott Williams \& Wilkins, 1999:643-724.

25 Pekkanen J, Sunyer J, Anto J, et al. Operational definitions of asthma in studies on its aetiology. Eur Respir J 2005;26:1-9.

26 Key TJ, Pike MC, Brown JB, et al. Cigarette smoking and urinary oestrogen excretion in premenopausal and post-menopausal women. Br J Cancer 1996;74:1313-6.

27 Espeland MA, Stefanick ML, Kritz-Silverstein D, et al. Effect of postmenopausal hormone therapy on body weight and waist and hip girths. Postmenopausal Estrogen-Progestin Interventions Study Investigators. J Clin Endocrinol Metab 1997;82:1549-56.

28 Harlow SD, Crawford SL, Sommer B, et al. Self-defined menopausal status in a multi-ethnic sample of midlife women. Maturitas 2000;36:93-112.

29 Bruning PF, Bonfrer JM, Hart AA, et al. Body measurements, estrogen availability and the risk of human breast cancer: a case-control study. Int J Cancer 1992;51:14-9.

30 Barrett-Connor E, Frette C. NIDDM, impaired glucose tolerance, and pulmonary function in older adults. The Rancho Bernardo Study. Diabetes Care 1996;19:1441-4. 
31 Dandona P, Aljada A, Bandyopadhyay A. Inflammation: the link between insulin resistance, obesity and diabetes. Trends Immunol 2004;25:4-7.

32 Fernandez-Real JM, Broch M, Richart C, et al. CD14 monocyte receptor involved in the inflammatory cascade and insulin sensitivity. $J$ Clin Endocrinol Metab 2003;88:1780-4.

33 Engstrom G, Hedblad B, Nilsson $P$, et al. Lung function, insulin resistance and incidence of cardiovascular disease: a longitudinal cohort study. J Intern Med 2003;253:574-81.

34 Davis WA, Knuiman M, Kendall P, et al. glycemic exposure is associated with reduced pulmonary function in type 2 diabetes: the Fremantle Diabetes Study. Diabetes Care 2004;27:752-7.
35 Lawlor DA, Ebrahim S, Smith GD. Associations of measures of lung function with insulin resistance and type 2 diabetes: findings from the British Women's Heart and Health Study. Diabetologia 2004;47:195-203.

36 Kirsch EA Yuhanna IS, Chen Z, et al. Estrogen acutely stimulates endothelial nitric oxide synthase in $\mathrm{H} 441$ human airway epithelial cells. Am J Respir Cell Mol Biol 1999;20:658-66.

37 Keller AC, Rodriguez D, Russo M. Nitric oxide paradox in asthma. Mem Inst Oswaldo Cruz 2005; 100(Suppl 1):19-23.

38 Simpson ER, Misso M, Hewitt KN, et al. Estrogen-the good, the bad, and the unexpected. Endocr Rev 2005;26:322-30.

\section{Clinical Evidence-Call for contributors}

Clinical Evidence is a regularly updated evidence-based journal available worldwide both as a paper version and on the internet. Clinical Evidence needs to recruit a number of new contributors. Contributors are healthcare professionals or epidemiologists with experience in evidence-based medicine and the ability to write in a concise and structured way.

Areas for which we are currently seeking contributors:

- Pregnancy and childbirth

- Endocrine disorders

- Palliative care

- Tropical diseases

We are also looking for contributors for existing topics. For full details on what these topics are please visit www. clinicalevidence.com/ceweb/contribute/index.jsp

However, we are always looking for others, so do not let this list discourage you.

Being a contributor involves:

- Selecting from a validated, screened search (performed by in-house Information Specialists) epidemiologically sound studies for inclusion.

- Documenting your decisions about which studies to include on an inclusion and exclusion form, which we keep on file.

- Writing the text to a highly structured template (about 1500-3000 words), using evidence from the final studies chosen, within 8-10 weeks of receiving the literature search.

- Working with Clinical Evidence editors to ensure that the final text meets epidemiological and style standards.

- Updating the text every 12 months using any new, sound evidence that becomes available. The Clinical Evidence in-house team will conduct the searches for contributors; your task is simply to filter out high quality studies and incorporate them in the existing text.

If you would like to become a contributor for Clinical Evidence or require more information about what this involves please send your contact details and a copy of your CV, clearly stating the clinical area you are interested in, to CECommissioning@bmigroup.com.

\section{Call for peer reviewers}

Clinical Evidence also needs to recruit a number of new peer reviewers specifically with an interest in the clinical areas stated above, and also others related to general practice. Peer reviewers are healthcare professionals or epidemiologists with experience in evidence-based medicine. As a peer reviewer you would be asked for your views on the clinical relevance, validity, and accessibility of specific topics within the journal, and their usefulness to the intended audience (international generalists and healthcare professionals, possibly with limited statistical knowledge). Topics are usually 1500-3000 words in length and we would ask you to review between 2-5 topics per year. The peer review process takes place throughout the year, and out turnaround time for each review is ideally 10-14 days. If you are interested in becoming a peer reviewer for Clinical Evidence, please complete the peer review questionnaire at www. clinicalevidence.com/ceweb/contribute/peerreviewer.jsp 
Table 1 Statistical analysis of the case-control study

\begin{tabular}{|c|c|c|c|c|c|c|c|c|c|c|c|c|}
\hline & \multicolumn{4}{|c|}{ Co-dominant } & \multicolumn{4}{|c|}{ Dominant (AA/AG v GG) } & \multicolumn{4}{|c|}{ Recessive (AA v AG/GG) } \\
\hline & AA & AG & GG & $\begin{array}{l}\mathrm{p} \\
\text { value }\end{array}$ & AA/AG & GG & OR $(95 \% \mathrm{Cl})$ & $\begin{array}{l}\mathrm{P} \\
\text { value }\end{array}$ & AA & GG/AG & OR $(95 \% \mathrm{Cl})$ & $\begin{array}{l}\mathrm{P} \\
\text { value }\end{array}$ \\
\hline Controls & $84(41 \%)$ & $82(41 \%)$ & $36(18 \%)$ & & 166 & 36 & & & 84 & 116 & & \\
\hline Cases & $99(47 \%)$ & $93(44 \%)$ & $18(9 \%)$ & 0.021 & 192 & 18 & 2.31 (1.27 to 4.23$)$ & 0.006 & 99 & 111 & 1.25 (0.85 to 1.85$)$ & 0.276 \\
\hline Acute & $30(42 \%)$ & $32(45 \%)$ & $9(13 \%)$ & 0.576 & 62 & 9 & $1.49(0.68$ to 3.28$)$ & 0.358 & 30 & 41 & $0.99(0.57$ to 1.71$)$ & 0.97 \\
\hline Chronic & 59 (52\%) & $47(41 \%)$ & $8(7 \%)$ & 0.021 & 106 & 8 & 2.87 (1.29 to 6.42$)$ & 0.007 & 59 & 55 & $0.67(0.43$ to 1.07$)$ & 0.095 \\
\hline
\end{tabular}

(95\% CI 1.29 to 6.42), $\mathrm{p}<0.0069$; table 1) with a PAR for AA homozygotes and AG heterozygotes of $50 \%$.

This study underlines the importance of the association of BTNL2 rs2076530 variant with the susceptibility to develop sarcoidosis in a German population. Furthermore, our data suggest that susceptibility is preferentially towards the chronic form of the disease.

Y Li, B Wollnik

Center for Molecular Medicine Cologne (CMMC) and Institute of Human Genetics, University of Cologne,

Germany

S Pabst, M Lennarz

Medizinische Universitäts-Poliklinik, RheinischeFriedrich-Wilhelms Universität Bonn, Germany

E Rohmann

Center for Molecular Medicine Cologne (CMMC) and Institute of Human Genetics, University of Cologne, Germany

A Gillissen

Städtisches Klinikum St Georg, Leipzig, Germany

H Vetter, C Grohé

Medizinische Universitäts-Poliklinik, RheinischeFriedrich-Wilhelms Universität Bonn, Germany

Correspondence to: Professor Dr med C Grohé, Medizinische Universitäts-Poliklinik, Wilhelmstr, 35 37, D-53111 Bonn, Germany; c.grohe@uni-bonn.de

$$
\text { doi: 10.1136/thx.2005.056564 }
$$

Competing interests: none.

\section{References}

1 Newman LS, Rose CS, Maier LA. Sarcoidosis. N Engl J Med 1997;336:1224-34.

2 Rybicki BA, lannuzzi MC, Frederick MM, et al. ACCESS Research Group. Familial aggregation of sarcoidosis. A case-control etiologic study of sarcoidosis (ACCESS). Am J Respir Crit Care Med 2001; 164:2085-91.

3 Valentonyte R, Hampe J, Huse K, et al. Sarcoidosis is associated with a truncating splice site mutation in BTNL2. Nat Genet 2005;37:357-64.

4 Rybicki BA, Walewski JL, Maliarik MJ, et al. ACCESS Research Group. The BTNL2 gene and sarcoidosis susceptibility in African Americans and Whites. Am J Hum Genet 2005;77:491-9.

5 Costabel U, Hunninghake GW. Statement on sarcoidosis. Joint Statement of the American Thoracic Society (ATS), the European Respiratory Society (ERS) and the World Association of

Sarcoidosis and Other Granulomatous Disorders (WASOG) adopted by the ATS Board of Directors and by the ERS Executice Committee. Am J Respir Crit Care Med 1999;160:736-55.

\section{Asthma and allergies in Germany}

We read the study by Zöllner and colleagues published recently in Thorax about the levelling off of asthma and allergies among children in Germany between 1992 and 2001. ${ }^{1}$ We have published a study looking at the same issue and using a similar protocol (ISAAC) $^{2}$ to assess the symptoms, diagnosis, and severity of asthma and allergies in more than 15000 children aged 6-7 and 1314 years between 1995 and 2000 in Münster, Germany. ${ }^{3}$ We found a tendency towards an increase in current symptoms of asthma and allergies in both age groups, but more so among girls. ${ }^{3}$

Indices of diagnosis either remained the same or increased in parallel with the increase in symptoms, arguing against a change in diagnostic behaviour as an explanation for our results. Indices of severity also showed a homogenous increase in the 5 year study period, pointing towards an increase in the overall burden of asthma and allergies within the society. ${ }^{3}$

Regrettably, these results, coming from Germany, were not considered in either the discussion of Zöllner's report or in the affirmative title that no increase in asthma and allergies occurred in Germany in the 1990s. Even more regrettable is the fact that when our study was alluded to in the discussion and conclusion of the paper by Zöllner et al, it was cited-contrary to our results-as one of the studies showing a decrease or levelling off of asthma and allergies among children. ${ }^{1}$

W Maziak, U Keil Institute of Epidemiology and Social Medicine, University Clinic of Muenster, Muenster, Germany; maziak@net.sy

\section{References}

1 Zöllner IK, Weiland SK, Piechotowski I, et al. No increase in the prevalence of asthma, allergies, and atopic sensitisation among children in Germany: 1992-2001. Thorax 2005;60:545-8.

2 Asher MI, Keil U, Anderson HR, et al. International Study of Asthma and Allergies in Childhood (ISAAC): rationale and methods. Eur Respir J 1995;8:483-91.

3 Maziak W, Behrens T, Brasky TM, et al. Are asthma and allergies in children and adolescents increasing? Results from ISAAC phase I and phase III surveys in Münster, Germany. Allergy 2003;58:572-9.

\section{Authors' reply}

Unfortunately, the paper by Maziak et al published in Allergy was listed as reference number 18 instead of number 21 in the reference list of our paper. ${ }^{2}$ We apologise for any misunderstanding which may have arisen from this error. A correction is published below.

In the paper by Maziak et $a l^{1}$ the prevalences in 1994/5 and 1999/2000 are compared. As we know from our own studies, trend analyses based on (only) two time points may be difficult and should be interpreted with caution. Indeed, in their investigation Maziak et al did not find a significant increase in the lifetime prevalence of asthma and hay fever, except in one subgroup. The effect found in 13-14 year old girls could also be due to a former underdiagnosis of asthma in girls, as discussed in their paper.

Since our results are based on six cross sectional surveys, we consider the title and the conclusion-that we did not see an increase in asthma and allergies from 1992 to 2001 - to be appropriate.

I Zöllner

Department of Epidemiology and Health Reporting, Baden-Wuerttemberg State Health Office, Wiederholdstr 15, D-70174 Stuttgart, Germany; Iris.Zoellner@rps.bwl.de

\section{Reference}

1 Maziak W, Behrens T, Brasky TM, et al. Are asthma and allergies in children and adolescents increasing? Results from ISAAC phase I and phase III surveys in Münster, Germany. Allergy 2003;58:572-9

2 Zöllner IK, Weiland SK, Piechotowski, et al. No increase in the prevalence of asthma allergics, and atopic sensitisation among children in

Germany: 1992-2001. Thorax 2005;60:545-8.

\section{CORRECTIONS}

doi: 10.1136/thx.2005.029561 corr 1

In the paper entitled "No increase in the prevalence of asthma, allergies, and atopic sensitisation among children in Germany: 1992-2001" by I K Zöllner et al which appeared in the July 2005 issue of Thorax (2005; 60:545$8)$, the authors apologise for a mistake which occurred in the reference list. Reference number 18 should be number 21 and references 19-21 should be listed as 18-20.

\section{doi: 10.1136/thx.2005.040444corr 1}

The paper entitled "Anticholinergics in the treatment of children and adults with acute asthma: a systematic review with meta-analysis" by G J Rodrigo and J A Castro-Rodriguez (10.1136/thx.2005.040444) has been published previously on 17 June 2005 as a Thorax Online First article but under the incorrect DOI (10.1136/thx.2005.047803). The publishers apologise for this error. The definitive version of the article can be found at the following citation: Thorax 2005;60:740-6.

doi: 10.1136/thx.2005.040881 corr 1

In the paper entitled "Hormone replacement therapy, body mass index and asthma in perimenopausal women: a cross sectional survey" by F Gómez Real et al published in the January 2006 issue of Thorax (2006;61:34-40), the fourth author should be K A Franklin, not K Franklin. 